\title{
NEOGENNÍ ZPĚTNÁ ROTACE VRÁSOVO-NÁSUNOVÉ STAVBY VE SPODNIIM KARBONU KRY MALENÍKU
}

\author{
Neogenne back-rotation of the Variscan fold-thrust system in the Lower Carboniferous \\ of the Maleník block
}

Josef Havíř $\square$

Ústav fyziky Země, PřF MU, Tvrdého 12, 60200 Brno

Key words: Moravian-Silesian Palaeozoic, Tertiary compression, bookshelf structure, folds, thrusts, Neogene reactivation

\begin{abstract}
In the frame of the geological mapping projects, geometry of the Variscan fold-thrust system of the Lower Carboniferous units on the SE margin of the Nízký Jeseník Highland and in the Maleník block was studied. This system consists of asymmetric kilometric folds and NW to WNW dipping thrusts. It is evident, that the fold geometry observed at sites on the SE margin of the Nizký Jeseník is almost the same as the fold geometry studied in the quarries in the Malenik block. The only difference consist in north-westwards tilting of the fold geometry in the studied area with respect to situation on the NE margin of the Nizký Jesenik. This tilting corresponds to the up to $40^{\circ}$ rotation around the sub-horizontal axis, which is sub-parallel to fold axes of the tectonic large ( $\left.k m\right)$ folds. It indicates that there is mutual relationship between the discussed rotation and the reactivation of the Variscan fold-thrust system. The main features of structural model are introduced in the article to explain the discussed rotation. The model supposes compressional back-rotation of the block connected with reactivation of Variscan thrusts. The block was steepened as a result of the shear movements associated with overthrust above the Lower Carboniferous units approximately from SE to NW. Known evidences of the Neogene reactivation of the Variscan thrusts allow assumption, that this overthrusting body was a frontal part of the Western Carpathian Nappe system.
\end{abstract}

Úvod

Při geologickém mapování prováděném na několika listech pokrývajících jv. okraj Nízkého Jeseníku a kru Maleníku (obr. 1) bylo zjištěno, že celá geometrie vrásovo-násunové struktury ve kře Maleníku (a také v lomu Veselíčko vj. části jv. okraje Nízkého Jeseníku) je oproti jv. okraji Nízkého Jeseníku výrazně ukloněna směrem $\mathrm{k} Z$ až SZ. Ve východní části kry Maleníku jde o úklon asi o $20^{\circ}$ až $30^{\circ}$ (Havír et al. 2003), ve střední a v z. části pak byla velikost diskutovaného úklonu na základě měření v lomu Podhůra vyčíslena na přibližně $40^{\circ}$ (Havír 2016). Porovnání strukturních prvkủ zjišstěných při mapování na listu 25-132 Lipník n. Bečvou s geometrií vrás na v. okraji Nízkého Jeseníku přitom ukazuje, že k výše diskutovanému uklonění geometrie vrásovo-násunové stavby ve kře Maleníku došlo rotací kolem horizontální či jen mírně ukloněné osy, která byla subparalelní $\mathrm{s}$ osami řádově kilometrových vrás. Smyslem tohoto článku je předběžně (alespoň v hlavních rysech) představit model, který tuto rotaci vrásovo-násunové stavby vysvětluje, tak, aby s ním mohla být seznámena širší odborná veřejnost dříve, než bude připravena a publikována podrobnější práce.

\section{Geologie a tektonická stavba studované oblasti}

Jak na jv. okraji Nízkého Jeseníku, tak i ve kře Maleníku vychází na povrch kulmské sedimenty (siliciturbidity) moravického a hradecko-kyjovického souvrství stárí svrchního visé (Dvořák 1994). Kulmské sedimenty tvoří variský př́krov oddělený plochou odlepení (decollement) od podložních svrchnodevonských až spodnokarbon-

$\square$ havir@ipe.muni.cz

DOI: https://doi.org/10.5817/GVMS2018-1-2-86 ských platformních karbonátů jednotky Moravského krasu (Čížek, Tomek 1991), které v prostoru Hranického krasu vystupují na povrch (Otava et al. 2016).

Dominantním prvkem tektonické stavby zmíněných kulmských sedimentů ve studovaném prostoru je východovergentní vrásovo-násunová stavba (Grygar, Vavro 1995), která je typickým prvkem tzv. tence násunového př́íkrovového systému (viz Čížek, Tomek 1991). Velmi dobře lze v terénu pozorovat především asymetrické východovergentní vrásy řádově kilometrových rozměrů se subhorizontálními či jen mírně ukloněnými osami orientovanými ve směru SV-JZ až SSV-JJZ (obr. 2). Tyto vrásy jsou geneticky spjaty s násuny ukloněnými $\mathrm{k} \mathrm{SZ}$ až ZSZ, které jsou v prostoru Nízkého Jeseníku dokumentovány např. na seismických profilech interpretovaných Čížkem a Tomkem (1991). Směrem do hloubky se násunové plochy stáčí a přechází do hlavní plochy odlepení na bázi tělesa prríkrovu tvořeného kulmskými sedimenty.

Přímé pozorování $\mathrm{v}$ Hranickém krasu i seismické profily na jiných místech ukazují, že také karbonáty v podloží př́ikrovu tvořeného kulmskými sedimenty mají intenzivní šupinovou stavbu spojenou s variskou tektonikou, tvořenou $\mathrm{k} \mathrm{Z}$ až SZ ukloněnými plochami foliace a variskými násuny (Dvořák 2004; Havír et al. 2003; Krejčí et al. 2002; Otava et al. 2016).

Výše diskutovaná variská stavba je pak dále komplikována strmými zlomy tzv. sudetského zlomového systému (ve smyslu Suka et al. 1996) směru SZ-JV. Zlomy tohoto systému byly založeny již během variské orogeneze, následně pak byly $\mathrm{v}$ různých obdobích opakovaně reaktivovány (např. Aleksandrowski et al. 1997; Grygar, Jelínek 2003; Špaček et al. 2015).

Na sedimentech paleozoika leží transgresivně klastika karpatské předhlubně karpatského a spodno- 


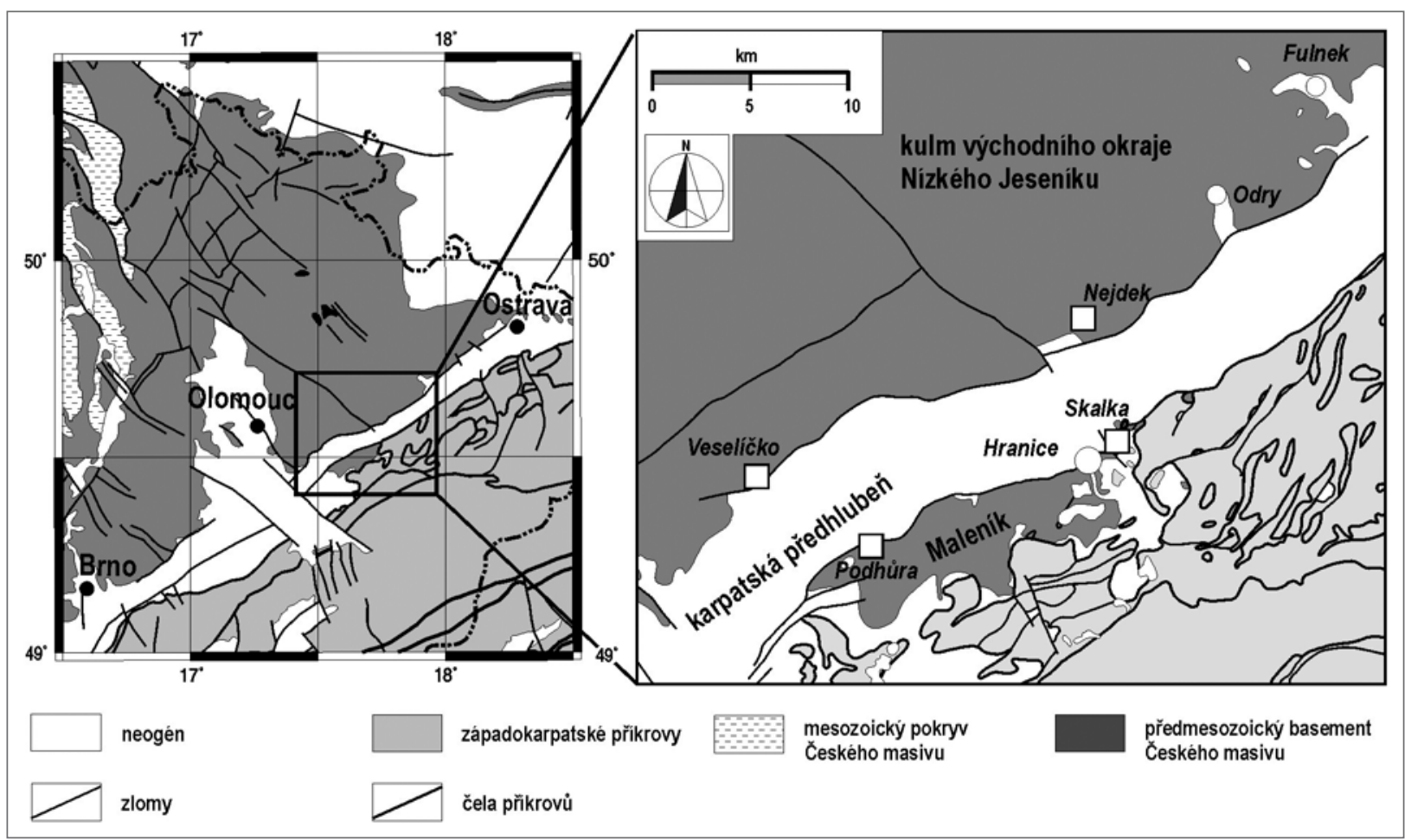

Obr. 1: Schematická geologická mapa regionu jv. okraje Nízkého Jeseníku a kry Maleníku (vlevo: sestaveno a modifikováno podle Kodyma et al. 1967 a Mahel'a et al. 1973; vpravo: podle Rotha 1990, zjednodušeno) s vyznačenými pozicemi lomů zmíněných v textu (Nejdek, Podhůra, Skalka a Veselíčko).

Fig. 1: Geological scheme of the SE part of the Nízký Jeseník and area of the Maleník block (left: compiled and modified after Kodym et al. 1967 and Mahel' et al. 1973; right: after Roth 1990, simplified) with locations of quarries mentioned in the text (Nejdek, Podhůra, Skalka and Veselíčko).

badenského stáríi. V důsledku vyklenování alpínského předpolí docházelo v tomto předpolí k vytváření poklesů uklánějících se obecně k JV. Počátek spodnobadenské sedimentace tak byl spojen s aktivitou extenzních struktur (poklesy, flexurní ohyby) tvořících současný okraj vyzdviženého prostoru Nízkého Jeseníku vůči karpatské předhlubni (Jurková 1976, 1985). Předbadensky aktivní struktury, např. poklesy limitující současné rozšíření sedimentů karpatu, lze hledat více na JV od recentních svahů Nízkého Jeseníku (Jurková 1985). Největší mocnosti neogenních sedimentů karpatské předhlubně se nachází v depresi Moravské brány. V západní části (tzv. Bečevská

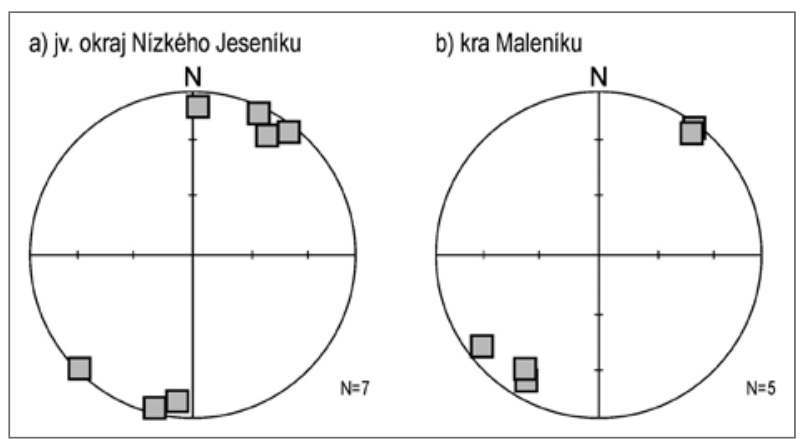

Obr. 2: Bodové diagramy os řádově kilometrových vrás na jv. okraji Nízkého Jeseníku (vlevo) a v prostoru kry Maleníku (vpravo).

Fig. 2: Diagram of fold axes of large $(\mathrm{km})$ folds on the SE margin of the Nízký Jeseník (left) and in the area of Maleník block (right). brána) reprezentuje Moravská brána hluboko erodovanou depresi, ve které schází kulmské sedimenty a na paleozoických karbonátech leží prímo spodnobadenská klastika (Czudek, Dvořák 1989; Jurková 1971).

Od J a JV jsou na podloží tvořené jednotkami Českého masivu a na neogenní sedimenty karpatské předhlubně nasunuty vnější západokarpatské příkrovy. Seismické profily ukazují, že v sv. části Moravské brány došlo k dosouvání čela západokarpatských příkrovů přinejmenším ve dvou etapách, přičemž dosunutí starších příkrovů reprezentovaných podslezskou jednotkou bylo předbadenské, zatímco prríkrovová tělesa dosunutá v průběhu mladší etapy jsou nasouvána také na sedimenty spodního badenu (Jurková 1971, 1985; Krejčí et al. 2002). Ve zmíněné sv. části Moravské brány zasahují příkrovová tělesa starší i mladší etapy až do prostoru Moravské brány. Oproti tomu v jz. části Moravské brány (v Bečevské bráně) současné rozširrení těles západokarpatských příkrovů nesahá za elevaci kry Maleníku (Czudek, Dvořák 1989; Jurková 1971). Vyklenutá struktura (tzv. slavkovsko-těšínský hřbet), jejíž součástí je kra Maleníku, přitom pokračuje dále $\mathrm{k}$ VSV, přičemž u Hranic se v. pokračování této elevace noří pod západokarpatské př́íkrovy (Dlabač, Menčík 1964; Jurková, Menčík 1983).

\section{Geometrie vrásovo-násunové stavby ve studovaném prostoru}

Geometrie řádově kilometrových východovergentních vrás byla sledována $\mathrm{v}$ řadě lomů situovaných na jv. 
okraji Nízkého Jeseníku a ve kře Maleníku (např. Havíř 2003, 2016).

Ohyb v zámkové oblasti kilometrových vrás je obvykle náhlý, zámková oblast má většinou jen řádově metrové rozměry a ve srovnání s rozměry ramen je tak velmi malá (Havír 2003). Zatímco v prostoru kry Maleníku je jedno rameno středně ukloněné a nepřekocené a druhé je strmé, místy subvertikální až strmě překocené, v jv. části Nízkého Jeseníku (s výjimkou j. části, tj. okolí Veselíčka) bylo ve vrásové stavbě obvykle pozorováno jedno subhorizontální či jen mírně ukloněné rameno v normální poloze a druhé překocené středně ukloněné rameno. Meziramenní úhly jsou přitom v jv. části Nízkého Jeseníku a ve kře Maleníku podobné (cca $45^{\circ}$ až $\left.70^{\circ}\right)$. Porovnáme-li např. synformní ohyb řádově kilometrové vrásy pozorovaný v lomu Nejdek na jv. okraji Nízkého Jeseníku s podobným synformním ohybem (rovněž rádově kilometrové vrásy) pozorovaným v lomu Podhůra na sz. okraji kry Maleníku, vidíme, že obě vrásové geometrie se liší pouze tím, že vrásová stavba v lomu Podhůra je oproti situaci v lomu Nejdek ukloněná o $40^{\circ} \mathrm{k}$ ZSZ (obr. 3). Orientace vrásových os přitom zůstala přibližně stejná, liší se pouze sklony vrásových ramen a osních rovin.

Vrásová ramena řádově kilometrových vrás jsou pak na některých místech dále deformována. Jednak v nich vznikají tektonické šupiny různých rozměrů, přičemž plochy tvořící jejich tektonická omezení jsou zakřivené a přechází do ploch vrstevnatosti. Smysl střižné deformace reprezentované těmito tektonickými šupinami vesměs koresponduje se střižnou deformací spojenou s vysouváním jádra řádově kilometrové vrásy v průběhu ohýbání vrstev při vzniku vrásové struktury. Tento mechanismus ohybu se skluzem lze dobře doložit také četnými striacemi na vrstevních plochách v ramenech vrás, které odpovídají

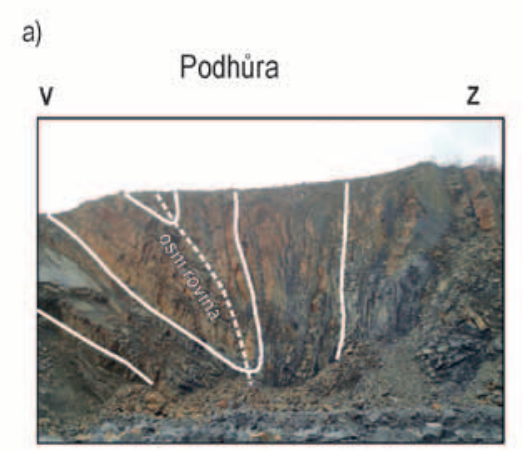

b)

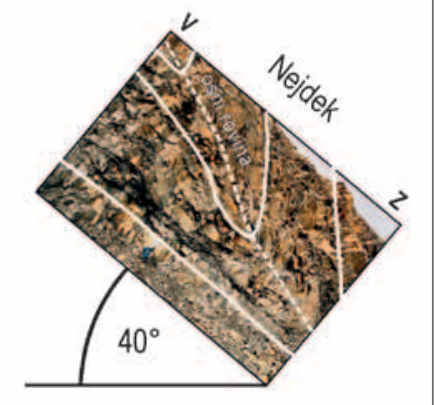

Obr. 3: Schematické znázornění geometrie synformního ohybu řádově kilometrové vrásy v lomu Podhůra v prostoru kry Maleníku (vlevo, foto autor) a porovnání s geometrií synformního ohybu řádově kilometrové vrásy v lomu Nejdek na jv. okraji Nízkého Jeseníku (vpravo, foto J. Otava). Oba snímky zachycují pohled od S k J. Geometrie kilometrové vrásy v lomu Podhůra odpovídá geometrii zjištěné v lomu Nejdek rotované o cca $40^{\circ} \mathrm{k} \mathrm{Z}$.

Fig. 3: Scheme of hinge zone geometry of large fold (synform) observed in the quarry Podhůra situated in the Maleník block (left, photo author) with comparison of geometry of similar tectonic kilometric fold (synform) in quarry Nejdek situated on the SE margin of the Nízký Jeseník area (right, photo J. Otava). Both pictures show view from N to S. Geometry of kilometric fold observed in quarry Podhůra corresponds to geometry of folds in quarry Nejdek rotated $40^{\circ}$ westwards. mezivrstevním prokluzům. Místy jsou vrásová ramena ké komplikována dalšími vrásovými strukturami, po decimetry.

Při vzniku vrásovo-násunové stavby hrály zásadní úlohu také $\mathrm{k}$ SZ až ZSZ ukloněné variské násuny. Asymetrické vrásy lze chápat jako projevy výrazné nekoaxia deformace $\mathrm{v}$ širším okolí násunů, která byla spojena pohyby podél násunových ploch. V terénu je ale že průběh hlavních násunových struktur lze očekávat $\mathrm{v}$ prostoru strmých, popř́padě překocených ramen asyve svých schématech také Čížek a Tomek (1991) či KumMartinec (1995).

$\mathrm{V}$ dnes již odtěžené části lomu Podhůra byly v roce 01 zjištěny přesmyky kulmských hornin přes spodnoaleníku, v lomu Skalka Cementárny Hranice (Havír,

Model zpětné rotace vrásové stavby v prostoru Maleníku

Rozdíl v geometrii vrásových systémů v jv. části Nízkého Jeseníku a ve kře Maleníku lze matematicky popsat rotací kolem subhorizontální osy směru SSV-JJZ ž SV-JZ, tedy subparalelní s osami řádově kilometrovrás, respektive se směrnicemi variských násunů. Zmíněná osa rotace tedy jeví geometrický vztah k orientaci vrásovo-násunové stavby a pokud tento vztah není čistě náhodný, ukazuje to, že diskutované uklonění k ZSZ až SZ souviselo s genezí či reaktivací prvků vrásovo-násunové stavby.

$\mathrm{V}$ lomu Veselíčko byly zjištěny $\mathrm{k} \mathrm{JV}$ ukloněné zlomové plochy se subhorizontálními striacemi, které sečou nepřekocené středně ukloněné rameno řádově kilometrové vrásy a jsou mladší, než tato vrása (nejsou ovlivněny mezivrstevními prokluzy). Při odstranění vlivu výše diskutované rotace kolem subhorizontální osy mají tyto zlomy charakter strmých horizontálních posunů (Haviŕr 2001), což ukazuje, že k diskutované rotaci došlo až po vzniku variské vrásovo-násunové stavby a že tedy souvisí nejspíše s její mladší reaktivací.

Pro zvážení možných mechanismů deformace spojené s diskutovanou rotací je důležitým faktem to, že kulmské sedimenty vytvářely $\mathrm{v}$ prostoru Maleníku přibližně kilometr mocné těleso reprezentující variský př́k rov oddělený od podloží bazální plochou, přičemž toto těleso bylo hustě imbrikováno variskými násuny (s ohledem na rozměry variských vrás lze odhadovat 


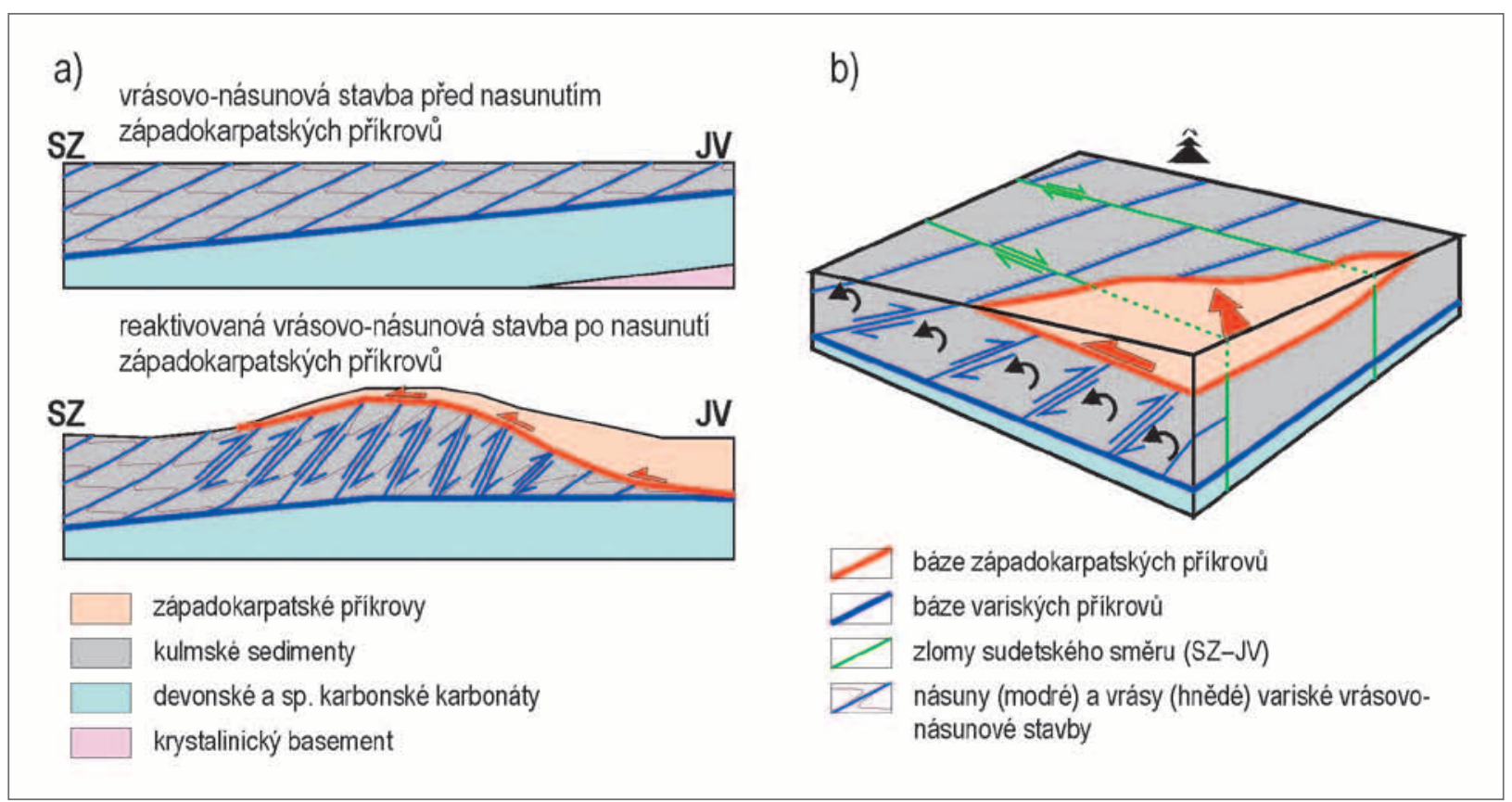

Obr. 4: Ideová schémata neogenní reaktivace původně variské tektonické stavby v kulmských sedimentech v prostoru kry Maleníku. a) Ideové schematické profily znázorňující tektonicky imbrikovanou jednotku kulmu s variskou vrásovo-násunovou stavbou před nasunutím západokarpatských př́krovů (nahoře) a následnou neogenní reaktivaci variských násunů a zpětnou rotaci tektonických bloků kulmských sedimentů v důsledku dosouvání západokarpatských př́íkrovů (dole). b) Ideové blokové schéma reaktivace původně variské tektonické stavby ve spodnokarbonských sedimentech v důsledku dosouvání západokarpatských př́krovů (blíže viz text).

Fig. 4: Scheme of the Neogene reactivation of the originally Variscan fold-thrust system in the Lower Carboniferous units exposed in the Block of Maleník. a) Schematic cross-sections illustrating tectonically imbricated Lower Carboniferous units with Variscan fold-thrust system prior to overthrust of the Western Carpathian Nappes (upper cross-section) and after this overthrust (lower cross-section). b) Schematic block-diagram of reactivation of the originally Variscan fold-thrust system in the Lower Carboniferous sediments as a result of the overthrust of the Western Carpathian Nappes (see text for details).

vzájemnou vzdálenost násunových ploch měřenou ve směru jejich normál na několik stovek metrů) a navíc bylo ještě dále segmentováno strmými sudetskými zlomy směru SZ-JV do pruhů širokých přibližně několik jednotek kilometrů. Těleso kulmských sedimentů tedy bylo $\mathrm{v}$ důsledku variských deformací tektonicky rozčleněné výše zmíněnými křehkými poruchami do šupinovitě se překrývajících bloků relativně malých (řádově kilometrových) rozměrů. Jako vhodný model reaktivace vrásovo-násunové stavby, který by vedl k pozorované rotaci geometrie vrásových systémů, se pak jeví dominový mechanismus spojený s reaktivací variských násunů (obr. 4). Oproti klasickému dominovému modelu ale v tomto př́padě charakter rotace horninových bloků odpovídá kompresní reaktivaci násunů a současně se stávají strmější.

Vzhledem $\mathrm{k}$ dokladům neogenní reaktivace variských násunů při dosouvání západokarpatských příkrovů (Havír., Otava 2004; Krejčí et al. 2002) lze diskutovanou dominovou rotaci s velkou pravděpodobností spojovat právě se střižnou deformací v podloží a před čelem dosouvajících se západokarpatských př́krovů. Pro vysvětlení rotace zasahující kulmské sedimenty nejen v prostoru kry Maleníku, ale také v okolí Veselíčka, by tak bylo zapotřebí předpokládat přesunutí západokarpatských příkrovů přes prostor kry Maleníku, a to patrně až k Veselíčku, tedy nejméně o cca $10 \mathrm{~km}$ dále oproti současné pozici čela západokarpatských př́krovů v tomto regionu.
Tento předpoklad je v případě staroštýrských příkrovů reálný. V severovýchodní části Moravské brány zasahuje současné čelo staroštýrských příkrovů pod badenskými sedimenty daleko do prostoru Moravské brány (např. Jurková 1985). Navíc v jz. části Moravské brány a v prostoru kry Maleníku je nutné počítat s významnou erozí, jednak v důsledku výzdvihu jv. okraje Nízkého Jeseníku a přilehlých částí karpatské předhlubně v době po dosunutí staroštýrských prríkrovů a před počátkem spodnobadenské sedimentace (Jurková 1971, 1976), a jednak v důsledku vyklenutí prostoru Maleníku, což bylo spojeno se vznikem strmější pozice horninových bloků při dominové rotaci. Takové časové zařazení reaktivace variských násunů a zpětné rotace by také dobře korelovalo se závěry Jurkové a Menčíka (1983) týkající se vzniku pohřbené části slavkovsko-těšínského hřbetu reprezentující pokračování elevace kry Maleníku.

Výše nastíněný model komplikuje fakt, že přesmyky kulmu přes spodnobadenská klastika v lomu Podhůra ukazují na badenskou či pobadenskou reaktivaci variských násunů, kterou by již bylo nutné korelovat s dosouváním mladoštýrských př́krovů. Mladoštýrská reaktivace by ale nevysvětlila dosah pozorované zpětné rotace až $\mathrm{k}$ Veselíčku, tedy do prostoru, který je v současné době oddělen od kry Maleníku hluboce erodovanou depresí vyplněnou spodnobadenskými klastiky. V době dosunutí staroštýrských př́ḱkrovů, na rozdíl od mladoštýrské etapy, 
zde tato překážka ještě nebyla. Proto je pravděpodobnější, že k hlavním změnám (ke zpětné rotaci) došlo již během staroštýrského dosunutí, i když mladoštýrské pohyby se také projevily menší či větší reaktivací křehkých poruch.

\section{Závěr}

Z výše diskutovaných faktů je možné vyvodit, že k vyklenutí elevace kry Maleníku došlo nejspíše v důsledku komprese spojené s dosunutím staroštýrských př́ikrovů, a to v době po uložení sedimentů karpatu, jejichž šupiny jsou j. od elevace Maleníku místy tektonicky zapracovány do západokarpatských příkrovů (viz Krejčí et al. 2002), a současně před uložením sedimentů spod- ního badenu. Vlivem deformace před čelem a v podloží dosouvaného staroštýrského prríkrovu došlo ke střižné kompresní reaktivaci variské vrásovo-násunové stavby. Variské násuny se při neogenní reaktivaci staly strmějšími, což se projevilo zpětnou rotací jimi oddělených horninových bloků a vedlo $\mathrm{k}$ uklonění geometrie variských vrásových struktur až o $40^{\circ} \mathrm{k} \mathrm{SZ}$ až ZSZ.

\section{Poděkování}

Př́spěvek vznikl s finanční podporou projektu ČGS číslo 321186 „Základní geologické mapování České republiky $1: 25000$ pro roky 2014-2018, oblast střední Morava“. Autor děkuje oběma recenzentưm za jejich pripomínky.

\section{Literatura}

Aleksandrowski, P., Kryza, R., Mazur, S., Żaba, J. (1997). Kinematic data on major Variscan strike-slip faults and shear zones in the Polish Sudetes, northeast Bohemian Massif. - Geological Magazine, 134, 5, 727-739. https://doi.org/10.1017/ S0016756897007590

Czudek, T., Dvořák, J. (1989). Vznik morfostruktury Moravské brány. - Sborník Československé geografické společnosti, 94, 4, 241-248.

Čížek, P., Tomek, Č. (1991). Large-scale thin-skinned tectonics in the Eastern boundary of the Bohemian Massif. - Tectonics, 10, 2, 273-286. https://doi.org/10.1029/89TC03241

Dlabač, M., Menčík, E. (1964). Geologická stavba autochtonního podkladu západní části vnějších Karpat na území ČSSR. - Rozpravy Československé akademie věd, řada matematických a př́rodních věd, 74, 1, 1-58.

Dvořák, J. (1994). Variský flyšový vývoj v Nízkém Jeseníku na Moravě a ve Slezsku. - Československý geologický ústav, Praha.

Dvořák, V. (2004). Orientační strukturní analýza vápenců Hranického krasu. - Geologické výzkumy na Moravě a ve Slezsku $\mathrm{v}$ roce $2003,42-45$.

Grygar, R., Jelínek, J. (2003). The Upper Morava and Nysa pull-apart grabens - the evidence of neotectonic dextral transtension on the Sudetic Fault System. - Acta Monatana IRSM AS CR, ser. A, 24, 51-59.

Grygar, R., Vavro, M. (1995). Evolution of Lugosilesian Orocline (north-eastern periphery of the Bohemian Massif): Kinematics of Variscan deformation. - Journal of Czech Geological Society, 40, 1-2, 65-90.

Havíŕ, J. (2001). Studium orientace hlavních os paleonapětí v širším okolí Moravské Brány - Výsledky první etapy. - Geologické výzkumy na Moravě a ve Slezsku v r. 2000, 44-46.

Havír, J. (2003). Geometrie strukturních prvků na jv. okraji Nízkého Jeseníku a ve kře Maleníku - předběžné výsledky (měření a analýzy v roce 2002). - MS, ČGS. Brno.

Havír̆, J. (2016). Variský vrásový systém odkrytý v lomu Podhůra (sv. okraj Českého masivu, kra Maleníku). - Geologické výzkumy na Moravě a ve Slezsku, 23, 1-2, 66-70.

Havír, J., Dvořák, V., Otava, J. (2003). Nové výsledky strukturního studia Paleozoika okolí Hranic. - Geologické výzkumy na Moravě a ve Slezsku v roce 2002, 48-51.

Havír, J., Otava, J. (2004). Badenian deformations in Carpathian Foredeep; a case study from NE Moravia. - Scripta Facultatis Scientarium Naturalium Universitatis Masarykianae Brunensis, 31-32, 99-106.

Jurková, A. (1971). Vývoj badenské čelní hlubiny v Moravské Bráně a na Ostravsku. - Geologické práce, Správy, 57, 155-160.

Jurková, A. (1976). Stavba karpatské předhlubně a flyšových př́ikrovů na sv. Moravě. - Časopis pro mineralogii a geologii, 21, 4, 349-362.

Jurková, A. (1985). Moravská brána jako dědičná depresní morfostruktura. - Sborník GPO, 29, 129-133.

Jurková, A., Menčík, E. (1983). Vývoj epivariské platformy v předneoidním a neoidním období. - In: Menčík, E., Adamová, M., Dvořák, J., Dudek, A., Jetel, J., Jurková, A., Hanzlíková, E., Houša, V., Peslová, H., Rybářová, L., Šmíd, B., Šebesta, J., Tyráček, J., Vašíček, Z. (1983). Geologie Moravskoslezských Beskyd a Podbeskydské pahorkatiny, 171-173, Ústřední ústav geologický, Academia. Praha.

Kodym, O., Fusán, O., Matějka, A. (1967). Geologická mapa ČSSR 1 : 500 000. - Ústřední Ústav Geologický Praha.

Krejčí, O., Hanžl, P., Hubatka, F., Sedlák, J., Švancara, J. (2002). Hercynian and Alpine brittle deformation of the Bruno-Vistulicum and its sedimentary cover units in the footwall of the Outer Western Carpathians (E part of the Czech Republic). - Krystalinikum, 28, 145-167.

Kumpera, O., Martinec, P. (1995). The development of the Carboniferous accretionary wedge in the Moravian-Silesian Paleozoic Basin. - Journal of the Czech Geological Society, 40, 1-2, 47-63.

Mahel', M., Púchy, R., Varga, J. (1973). Tectonic map of the Carpathian-Balkan mountain system and adjacent areas $1: 1000000$. - GUDŠ Bratislava/UNESCO Paris. 
Otava, J., Bábek, O., Bubík, M., Buriánek, D., Čurda, J., Franců, J., Fürychová, P., Geršl, M., Gilíková, H., Godány, J., Havír, J., Havlín Nováková, D., Krejčí, O., Krejčí, V., Lehotský, T., Maštera, L., Novotný, R., Poul, I., Sedláčková, I., Skácelová, D., Skácelová, Z., Stráník, Z., Švábenická, L., Tomanová Petrová, P. (2016). Vysvětlivky k základní geologické mapě České republiky $1: 25$ 000, list 25 - 141 Kelč. Geologická mapa $1: 25000$ s textovými vysvětlivkami. 116 s. ČGS Praha.

Roth, Z. (1990). Geologická mapa ČSSR 1:200 000, M-33-XXIV Olomouc. - Ústřední Ústav Geologický Praha.

Suk, M., Reichwalder, P., Šefara, J., Schenk, V. (1996). Regionalizace v geologických vědách. - Folia Facultatis Scientiarum Naturalium Universitatis Masarykianae Brunensis, Geologia 38, 1-227.

Špaček, P., Bábek, O., Štěpančíková, P., Švancara, J., Pazdírková, J., Sedláček, J. (2015). The Nysa-Morava Zone: an active tectonic domain with Late Cenozoic sedimentary grabens in the Western Carpathians' foreland (NE Bohemia Massif). - International Journal of Earth Sciences (Geologische Rundschau), 104, 96-990. https://doi.org/10.1007/s00531-014-1121-7 